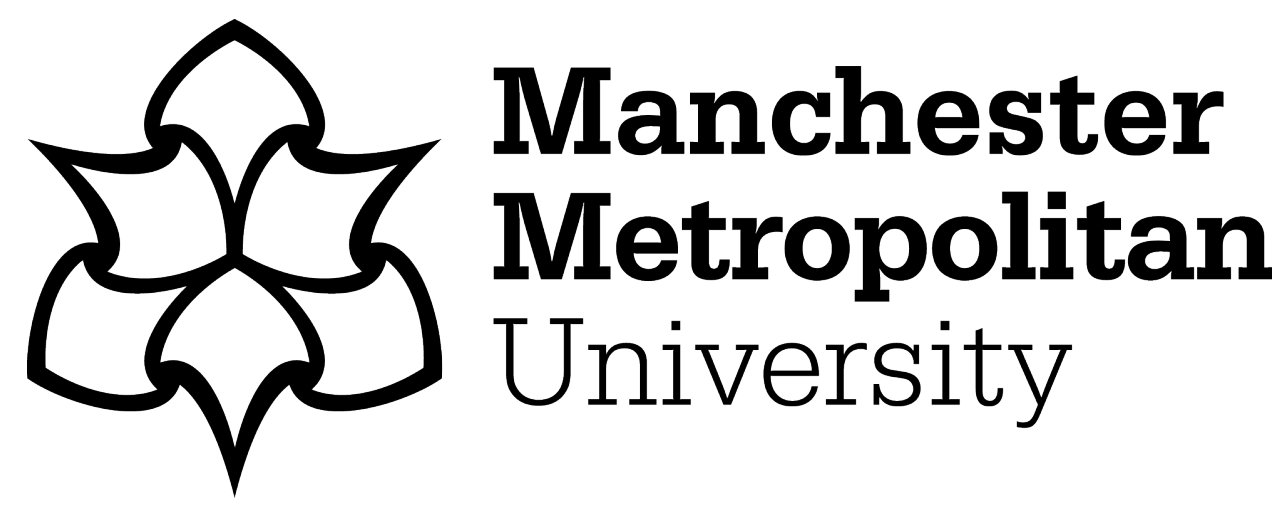

Cazeri, GT, Anholon, R, da Silva, D, Cooper Ordonez, RE, Goncalves Quelhas, OL, Filho, WL and de Santa-Eulalia, LA (2018) An assessment of the integration between corporate social responsibility practices and management systems in Brazil aiming at sustainability in enterprises. Journal of Cleaner Production, 182. pp. 746-754. ISSN 0959-6526

Downloaded from: https://e-space.mmu.ac.uk/620432/

Publisher: Elsevier

DOI: https://doi.org/10.1016/j.jclepro.2018.02.023

Usage rights: Creative Commons: Attribution-Noncommercial-No Derivative Works 4.0

Please cite the published version 
This paper was published at

Cazeri GT, Anholon R, da Silva D, Cooper Ordonez RE, Goncalves Quelhas OL, Leal Filho W, de Santa-Eulalia LA

JOURNAL OF CLEANER PRODUCTION 182:746-754 (9 pages) 01 May 2018

https://www.sciencedirect.com/science/article/pii/S0959652618303275

\title{
An assessment of the integration between corporate social responsibility practices and management systems in Brazil: aiming at sustainability in enterprises
}

\section{Research Highlights:}

- There is a need to evaluate the integration between CSR (corporate social responsibility) practices and management systems.

- We employed experts’ opinions to map how stakeholders' needs have been identified and translated to organizational practices in a way that ensures continuous improvements.

- We combined survey the method with multidimensional scaling and factor scores for data analysis.

- According to the experts’ perception, CSR practices are largely superficially implemented.

- Practices associated with planning of CSR activities are the most lightly implemented.

- Some recommendations on how to improve the use of CSR in an integrated management system are made.

\begin{abstract}
The concept of corporate social responsibility (CSR) is associated with the idea that every organization should integrate environmental, economic and social issues as part of their organizational philosophy. In companies with a higher degree of development in terms of CSR, sustainability practices are integrated into management systems. When focusing on Latin America, this integration may be at its first steps, but there is a vacuum in the literature in this field. Based on this reality, this paper aims to evaluate the integration between CSR practices and management systems in companies in Brazil based on experts' perceptions. Employing a conceptual model covering how stakeholder demands are incorporated in organizational practices using a continuous improvement approach, we performed a survey with experts in the area. Results revealed opportunities for improvements in all CSR practices evaluated, most of which were considered by the experts to have been implemented only superficially.
\end{abstract}


In a comparative analysis, two practices stood out in relation to the others: reporting of CSR results to stakeholders and evaluation of the performance of CSR activities using pre-established indicators. Practices associated with planning of CSR activities are the most superficially implemented, adversely affecting CSR performance. The authors believe that the findings of this study could be useful for business managers and academics as guidance towards improved CSR efforts.

Keywords: Corporate Social Responsibility (CSR); Integrated Management Systems (IMS); Brazilian Companies.

\section{INTRODUCTION}

There has been a change in the paradigm governing the objectives of businesses during recent decades. In his famous article in the New York Times Magazine in 1970, Milton Friedman argued that the main objective of a business was to maximize its profits and that the only restriction imposed on the business was the need to obey the law (Friedman, 1970; Scott and Davis, 2015). However, this scenario has changed over the last decades, and organizations are now obliged to achieve social and environmental objectives in order to satisfy the interests of all involved parties and ensure the organization’s long-term survival (García-Rodríguez et al., 2013; Mota et al., 2015; Galeazzo and Klassen, 2015). Quairel-Lanoizelée (2011) and Helleno et al. (2017) confirm this new scenario and note that organizations must evaluate the economic, social and environmental impacts of all their activities.

In this scenario emerges the concept of Corporate Social Responsibility (CSR). The European Commission (2011, n.d.) defines CSR as "the concept whereby companies integrate social and environmental concerns in their business operations and in their interaction with their stakeholders on a voluntary basis". According to the UN Department of Economic and Social Affairs (2007), CSR can be defined as "the overall contribution of business to sustainable development". Sprinkle and Maines (2010) argue that CSR practices can provide many benefits to organizations, such as: improvement in the image of the organization, greater employee motivation, better degree of communication with all stakeholders, reduction in the consumption of materials and energy, among others.

According to Cramer (2005), despite the many benefits reported in the literature for organizations that adopt CSR, there is still a lack of information on how to implement a structured approach toward CSR. Many studies have investigated the possibility of using an integrated management system (IMS) to implement CSR practices, as IMS has been deployed by various organizations with different levels of success (Mežinska et al., 2015). According to Jørgensen et al. (2006), integration has more characteristics than mere simple alignment. It involves the "rooting" of values, norms and processes in the organization, as well as direct interaction of these elements with stakeholders. Beckmerhagen et al. (2003) list eleven advantages of deploying IMS, including an improvement in system effectiveness and 
efficiency, elimination of duplicated effort and redundancies and increased synergy. Asif et al. (2013) notes that there are many gaps to be filled before companies can create true IMS that takes into consideration CSR practices, addresses the needs of all stakeholders and adds value. In fact, Asif et al. (2013) propose an interesting model for this integration and it will be used as the basis for this research.

Sobczak and Coelho Martins (2010), Abreu et al. (2012) and Halkos and Skouloudis (2016) note that there is a trend toward the harmonization of CSR practices in multinational organizations but that the cultural and legal traditions of a particular country continue to play an important role in the definition of relations between business and society. When defining CSR strategies and corresponding practices, company management should therefore search for a balance between respect for universal values, especially those embedded in emerging international standards, and respect for local values, such as the need to adapt to the different national contexts in which the company's subsidiaries or suppliers operate. In Latin America, in particular, CSR is still considered to be at the development stage and projects without a clearly defined scope or with conflicting aims are common (Lázaro and Gremaud, 2017; Pozas et al., 2015; Vives and Peinado, 2011). Focusing on Brazil, it is possible to observe a great discrepancy regarding the motivations and adoptions of CSR practices, as pointed out by Anholon et. al (2016).

In light of the above, the objective of this paper was to evaluate integration of CSR practices and management systems in companies in Brazil and to identify the best and least integrated practices. The integration model proposed by Asif et al. (2013) is discussed, and the perceptions of experts on CSR in Brazil are considered. A survey was carried out in which a questionnaire based on a list of representative CSR practices in the integration model proposed by Asif et al. (2013). The questionnaire was sent to 184 experts, of whom 48 replied (some modifications were made to the list proposed by Asif et al. (2013), as will be shown in Section 3). The research described by this paper is original, and a search of the literature failed to identify any other papers with the same scope. The authors believe that the results reported here may be of great value to practitioners and academics.

This paper is organized as follows: Section 2 (Theorical Framework) presents more details about CSR concepts, shows a panorama about Brazil CSR practices and discusses the model proposed by Asif et al. (2013). Section 3 (Methodology) presents the methodological procedures and provides sufficient details to allow the work to be reproduced by an independent researcher. Section 4 (Results) presents the main results of the survey and the statistical analysis; in Section 5 (Discussion), the findings are discussed in the light of the current literature on CSR; Section 6 (Conclusions) presents the main conclusions regarding the integration of CSR practices and management systems in companies in Brazil and makes some suggestions for possible future studies on this subject. 


\section{THEORICAL FRAMEWORK}

\subsection{Triple Bottom Line, Corporate Social Responsibility and the Brazilian panorama}

The need to assess the activities of an organization from an economic, social and environmental perspective emerged with the publication of the Brundtland Report “Our Common Future” in 1987 (World Commission on Environment and Development, 1987; Moldan et al., 2012). Another important milestone was the publication of the book Cannibals with Forks: The Triple Bottom Line of $21^{\text {st }}$ Century Business by Elkington, J. in 1997 (Shnayder et al., 2015). Elkington introduced the concept of the triple bottom line (TBL), a new approach to measuring the success of an organization's activities that considers social and environmental performance in addition to traditional financial performance (Elkington, 1998). The social dimension refers to the people involved with the organization and includes apart from training or the lack of it (Biasutti, Makrakis, Concina, Frate 2018), an organization's relationship with stakeholders, from shareholders to community members who are affected by its behavior, such as small farmers and communities near its facilities or suppliers.

The organization's employees, customers and consumers are also included in this category. The environmental dimension refers to the effects the organization has on the planet and includes sustainable supply, renewable energy, waste reduction and related issues. Finally, the financial dimension refers to profit and all issues related to the financial health of the organization, such as reduction of production costs, prospection of new markets and stockholders’ equity (Elkington, 1998; Asif et al., 2011; Shnayder et al., 2016).

According to Hubbard (2009), Roca and Searcy (2012) and Helleno et al. (2017), there are many different standards for measuring and evaluating the social and environmental dimensions of the TBL but no consensus regarding a common standard. Organizations often use complex measurement structures because of the difficulties involved in developing social and environmental indicators.

Despite these difficulties, academics and specialists agree that the TBL is a new approach to management that should be pursued (Glac, 2015). According to Douglas (2007) and Slaper and Hall (2011), organizations have increasingly reported their social and environmental activities and goals as these two areas now play a fundamental role in their decisions and support their development.

The concept of Corporate Social Responsibility (CSR) is directly associated with TBL's philosophy. According to Rahman (2011), there are many definitions of CSR in the literature. Dahlsrud (2008) identified thirty-seven and noted that these generally involve five main areas: environmental management, social management, economic management, stakeholder analysis and the encouragement of volunteering. Ashley (2005) considers CSR the commitment that an organization must have to society expressed through acts and attitudes that affect society positively either globally or locally. The 
organization therefore assumes moral obligations in addition to those established by law and must contribute to the sustainable development of society even if such obligations are not directly linked to its activities. Thus, social responsibility can be considered any and all actions that can contribute to an improvement in quality of life in society. More recently, Sarkar and Searcy (2016, pg 1433) proposed the following definition of CSR, which includes the organization's economic responsibility and is the one adopted here. The definition was based on a quantitative analysis of 110 existing definitions of CSR.

"CSR implies that firms must foremost assume their core economic responsibility and voluntarily go beyond legal minimums so that they are ethical in all of their activities and that they take into account the impact of their actions on stakeholders in society, while simultaneously contributing to global sustainability."

CSR practices have been found to be positively associated with an organization's competitiveness (Battaglia et al., 2014; Boulouta and Pitelis, 2014; European Comission, 2011, n.d.). According to Saeidi et al. (2015), Bernal-Conesa et al. (2016) and Esteban-Sanchez et al. (2017), CSR practices mitigate supply-chain risks, increase customer satisfaction and loyalty, make the organization more attractive to shareholders and have a positive effect on the organization's profitability. Jhunjhunwala (2014) also found that integration of CSR with an organization's business strategy increases the organization's chances of long-term success.

According to Bazillier and Vauday (2014) there is a current effort in order to establish a single global definition for CSR based on the actual rules, concepts and statements. ISO 26000 is a powerful example of this disposal. To ISO (2016, p. 3)

“ISO 26000:2010, Guidance on social responsibility, provides guidelines on how businesses and organizations can operate in a socially responsible way, displaying an ethical and transparent behavior that contributes to the health and welfare of society. This encourages them to go beyond legal compliance, recognizing that compliance with the law is a fundamental duty of any organization and an essential part of their social responsibility programme”

Besides ISO 26001, Delchet-Cochet and Vo (2013) also mention other important documents associated with corporate social responsibility such as: OECD guiding principles, Global Compact, ISO 14001 (environmental management system), SD 21000 (French standard related to CSR), Diag SD 2100 regulatory instrument), SA 8000 (Standard related to labor social rights), AA 1000 (reference document for stakeholders in account), VMS (German reference document for business ethics), GRI (Global Reporting Initiative) and Euro GR guidelines.

Focusing CSR practices in Latin America, it is possible to note that the CSR projects are in a development stage and they either do not have a clearly defined scope or they have conflicting aims, as mentioned in the introduction (Lázaro and Gremaud, 2017; Pozas et al., 2015; Vives and Peinado, 2011). 
In Brazilian companies especially, CSR practices are implemented to varying degrees. An interesting example can be found in a study by Anholon et al. (2016) that evaluated CSR practices in Embraer, a Brazilian aerospace company, and their level of integration in relation to the company's other management systems. The results indicated that Embraer, one of the most important companies in Brazil, has integrated CSR practices with other existing management systems in a harmonious, mature manner. Studies have also been carried out to compare the development of CSR in Brazil and other countries, such as the study by Abreu and Barlow (2013), which compared CSR in Brazil and the United Kingdom. They found that CSR practices in the UK are more related to law enforcement and focus on environmental issues, while in Brazil there is a need for a more systematic and rule-based approach.

According to Pelliano (2001), Passador (2002) and Griesse (2007), CSR practices are particularly relevant in Brazil because they can help to reduce the country’s great social inequality.

According to Vivarta and Canela (2006), businessmen, politicians, the community and the media in Brazil first became involved with CSR when Herbert de Souza launched a movement against hunger, which attracted private sector support. Like other subsequent campaigns launched by NGOs, the movement received widespread coverage in the media, which played a fundamental role in the development of CSR nationally. The campaign stood out in the prevailing business environment and culminated in the creation of the Ethos Institute of Business and Social Responsibility in 1998. In parallel with this, the media exerted a significant influence on the development of CSR discourse and practices in Brazil, although it dealt with the subject in a superficial way. Griesse (2007) points out that the wellknown sociologist Herbert de Souza launched a national TV campaign in the late 1990s promoting the idea of social reporting, leading to an increase in the number of companies in Brazil implementing CSR concepts and practices. By playing a key role in the dissemination of NGO campaigns and CSR practices in other parts of the world, the media outside Brazil contributed indirectly to the change in the CSR scenario in Brazil.

Finally, it is important to mention a performed by Borges et al. (2017), which analyzed 30 sustainability reports published between 2014 and 2015 by Brazilian companies. It identified improvement opportunities in the reports associated to better mapping and reporting of practices, stakeholder engagement and continuous improvement.

\subsection{Integration between CSR practices and management systems}


According to Castka et al. (2004), organizations are under increasing pressure to show that their CSR actions have been developed as an integral part of their management systems; accordingly, research papers have been published presenting frameworks that allow this level of integration. The following models have been highlighted in the last decades: "Pyramid of Corporate Social Responsibility" (Carroll, 1991 and Claydon, 2011), "Sustainable Development Model" (Aras and Crowther, 2009), "CSR 2.0" Visser (2010) and the approach to integrate management systems and corporate social responsibility developed by Asif et al. (2013).

Encompassing the main characteristics of the mentioned frameworks, Asif et al. (2013) presents a special address of the stakeholder demands in a top-down and bottom-up manner and then integrated into the management system using the Plan-Do-Check-Act (PDCA) cycle. These special features configure greater pragmatism to it which is relevant for the accomplishment of the objectives of this paper. Based on this scenario, the Asif et al. (2013) framework was chosen to mark out the survey questions of this paper. Fig. 1 illustrates this framework.

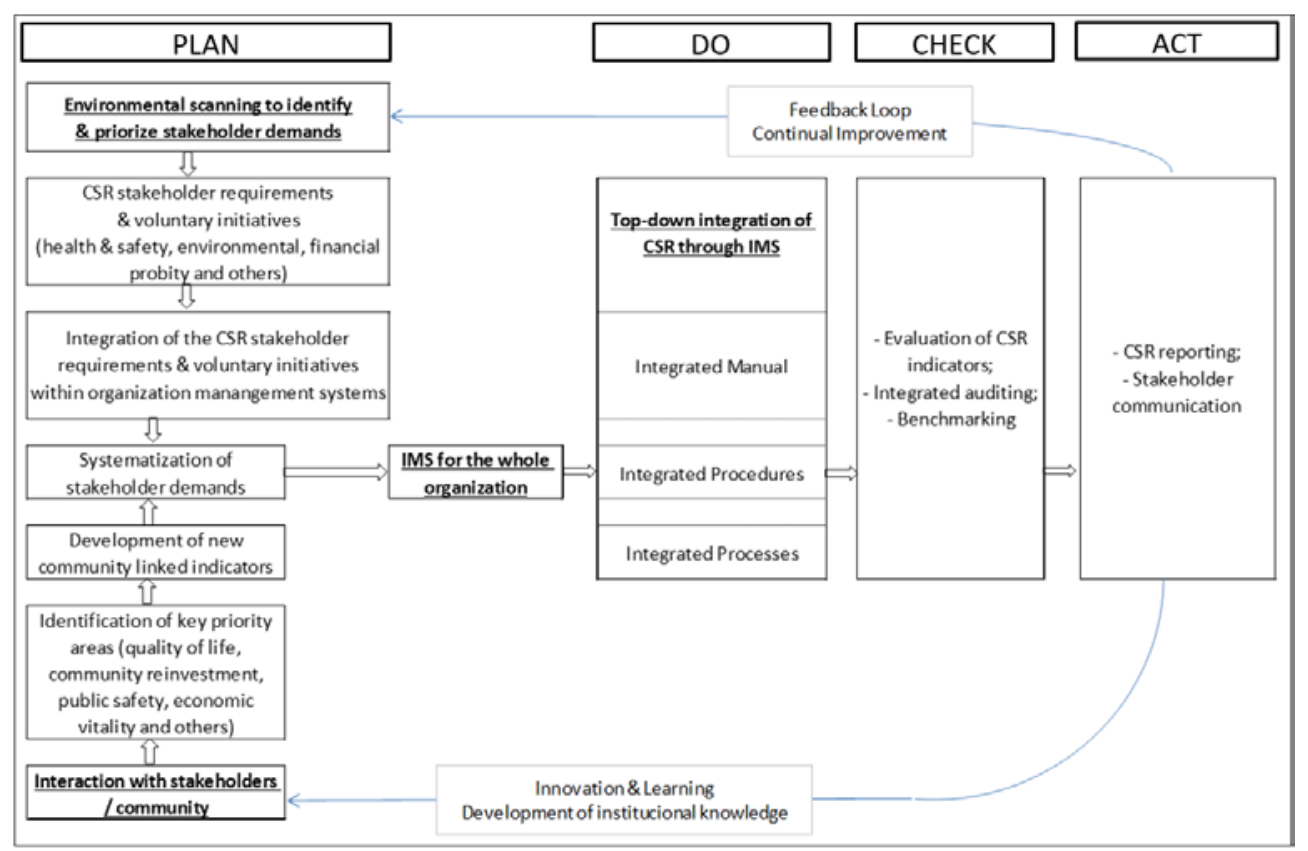

Fig. 1. Framework for integration of CSR activities in a company’s management system (Asif et al., 2013).

As shown in Fig. 1, the Plan stage of the PDCA cycle is characterized by identification of stakeholder needs in top-down and bottom-up approaches followed by systematization of the demands thus identified and a proposal for an integrated management system. For Asif et al. (2013), the planning is characterized as one of the most critical and important phases in efforts to integrate CSR practices into management systems. If there is a poor definition of objectives and actions at the mentioned phase, the global result may be lower than expected, according to Asif et al. (2013) and Caiado et al. (2017). In the Do stage of the PDCA cycle, the organizational infrastructure is adapted so that the organization can 
adopt a structured integrated system. Manuals, procedures and processes should be handled in an integrated manner to meet the needs of different stakeholders. In the Check stage of the PDCA cycle, measurement and evaluation are fundamental. The model implemented should be evaluated by means of CSR indicators, integrated audits and comparisons with benchmarks. Finally, the Act stage of the PDCA cycle is based on communication of the results achieved with CSR initiatives to stakeholders. This is normally done through, for example, annual reports, letters, dissemination of details of corporate philanthropic activities and websites. For the bottom-up approach, there is no standard model, and the organization must identify the most appropriate way of communicating with the wider community.

Once the different needs of stakeholders have been identified, the PDCA cycle should be repeated to ensure continuous improvement and evolution of the management system. In addition to the framework in Fig. 1, Asif et al. (2013) present in their article thirty-six practices for integrating CSR with management systems. The content of these practices will be presented in a compact way in the item Methodology, since these practices gave base to the questionnaire used in the survey.

\section{METHODOLOGY}

After performing a literature review to define the theoretical basis, as pointed out by Gil (2010), and to define the model used as a reference, a survey was employed to collect the opinion of the experts regarding the integration between the CSR practices and management systems. The survey was conducted electronically, since it has many advantages such as a lower overall cost, possibility of contact respondents from different regions or countries, among others. Surveys conducted electronically allow a more pragmatic approach (Evans and Mathur, 2005). These advantages justify our choice for the online survey. We employed a mixed-approach (qualitative and quantitative) as presented by Gray (2016). The qualitative part seeks to understand behaviors developed by managers, while the quantitative one uses a numerical scale to evaluate the stage of between CSR practices and management systems. To do so, we employed a questionnaire as the instrument for data collection.

The research started with a literature review, in scientific bases as Elsevier, Emerald, Springs, Periódico Capes (a Brazilian scientific database) and others using the terms "CSR" and "corporate social responsibility” associated to terms “integration”, “management system”, “integrated management system”, "triple bottom line”, “critical success factors" and "literature review”. After careful reading of the selected articles, we chose the main one to structure this research. Special attention was given to the Asif et al (2013) model, since it provides guidelines to help us define our conceptual framework and questionnaire to achieve our research objective.

The thirty six practices present in the Asif et al. (2013) model were carefully analyzed and, when possible, grouped according to their thematic similarity. It is important to highlight that this grouping 
was carried out without content loss in relation to the ideas proposed by Asif et al (2013). Thirty practices were generated through this action, as presented in Table 1.

Table 1. CSR practices evaluated by respondents (Adapted from Asif et al. (2013).)

\begin{tabular}{|c|c|}
\hline \multicolumn{2}{|r|}{ Plan phase } \\
\hline 1 & Perform an environmental scan to identify issues that impact the organization \\
\hline 2 & Define stakeholders and their requirements \\
\hline 3 & Ensure that there are no clashes of interest/redundancies in different stakeholders' requirements \\
\hline 4 & Ensure that different stakeholders' requirements do not pull organizational processes in different directions \\
\hline 5 & Engage in stakeholder consultation \\
\hline 6 & Define CSR in the context of the organization and develop a business model for it \\
\hline 7 & Explore individual and organizational competencies for CSR and clearly define responsibilities \\
\hline 8 & Develop global indicators and indicators to assess the performance of CSR \\
\hline 9 & Identify the resources required for CSR \\
\hline 10 & Secure top-management commitment \\
\hline \multicolumn{2}{|r|}{ Do phase } \\
\hline 11 & Integrate CSR by translating organizational objectives into tactical and operational ones \\
\hline 12 & Integrate CSR across departments, functions and the whole supply chain \\
\hline 13 & $\begin{array}{l}\text { Develop technical structures for CSR such as integrated manuals, } \\
\text { procedures, work instructions and processes }\end{array}$ \\
\hline 14 & Develop social structures such as teamwork, training and collective CSR competencies \\
\hline 15 & Align social and technical structures for CSR \\
\hline 16 & Develop a corporate culture that values CSR practices (long-term strategic CSR plans, codes of conduct, routines for CSR etc.) \\
\hline 17 & Manage CSR knowledge and lessons learned to improve CSR performance. \\
\hline 18 & Respond appropriately upon transgression \\
\hline 19 & Ensure transparency in the integration of CSR with the management systems implemented in the organization \\
\hline \multicolumn{2}{|r|}{ Check phase } \\
\hline 20 & Evaluate CSR performance using pre-set indicators \\
\hline 21 & Critically analyze the adequacy and functionality of CSR structures in light of the existing infrastructure \\
\hline 22 & Evaluate the adequacy of the integration between the CSR system and the management system implemented in the organization \\
\hline 23 & $\begin{array}{l}\text { Use different means for assessing CSR practices-such as integrated audits, self-assessment and benchmarking-to ensure holistic } \\
\text { assessment of CSR in both strategy and operations }\end{array}$ \\
\hline 24 & Monitor employees’ behavior in relation to CSR practices \\
\hline \multicolumn{2}{|r|}{ Act phase } \\
\hline 25 & Determine what to report in relation to CSR practices and the best way to do so \\
\hline 26 & Report CSR results to the stakeholders by means of annual reports, website updates, letters to shareholders etc. \\
\hline 27 & Present results aligned with the interests of stakeholders rather than just reporting stories and experiences related to the organization \\
\hline 28 & Integrate new CSR knowledge into organizational processes \\
\hline 29 & Promote continuous improvement in the integration of CSR strategies and operations with management processes. \\
\hline 30 & Consolidate procedures for continuous process improvement \\
\hline
\end{tabular}

Each of the 30 practices in Table 1 was evaluated by CSR experts in terms of the extent to which it was being applied in companies in Brazil. The authors of this article understand as "CSR experts" professionals who stand out in their field of activity field. These professionals can be acting as industry professionals, professors or researchers and consultants. The list of possible respondents was structured from Lattes Platform (a Brazilian base that groups curricula of researchers and practitioners), institutes' websites related to sustainability and sites of companies recognized by their sustainable management. Some names were also indicated by professionals who responded to the survey at a first glance. It is clear, therefore, that the sample used was non-probabilistic and by judgment. In this kind of sample the researcher selects the professionals who are judged to be the most apt and qualified to respond the survey. 
The CSR experts (respondents) were required to assign a score from 0 to 10 to each practice based on their experience of the context in which companies in Brazil operate. Scores were grouped in pairs, as shown in Table 2, to allow respondents to fine tune their responses.

Table 2. Scores and the corresponding degree to which the practice is applied (Source: The authors).

\begin{tabular}{|c|l|}
\hline Score & \multicolumn{1}{|c|}{ Extent to which the practice is applied } \\
\hline 0 & The practice is not applied by companies operating in Brazil; \\
\hline 1 or 2 & The practice is applied to a minimal extent by companies operating in Brazil; \\
\hline 3 or 4 & The practice is applied superficially by companies in Brazil, and there are ample opportunities for improvement; \\
\hline 5 or 6 & The practice is applied in a standardized manner by companies in Brazil, but there are still possibilities for improvement; \\
\hline 7 or 8 & $\begin{array}{l}\text { The practice is applied in a standardized and well-structured manner by companies in Brazil but is not integrated with their management } \\
\text { systems; }\end{array}$ \\
\hline 9 or 10 & The practice is applied in a standardized, well-structured manner by companies in Brazil and is integrated with their management systems. \\
\hline
\end{tabular}

The questionnaire was sent to 184 experts, and after three months 48 questionnaires had been answered (a return rate of 26\%). It was clearly stated that the questionnaire should be answered based on the respondent's knowledge of the situation in Brazil as a whole, rather than his/her knowledge of the situation in specific companies. It is important to note that the questionnaire was composed of two parts, the first one associated to the respondents' characterization and the second one associated to the assessment of 30 practices mentioned.

The data were compiled in an Excel spreadsheet and analyzed using Statistical Package for Social Sciences (SPSS). Two statistical analyses were performed: (1) multidimensional scaling (MDS) to identify outlier respondents; and (2) factor scores to order CSR practices.

According to Carroll and Arabie (1980) and Davison (1983) in Scholten and Caldeira (1997), MDS is a statistical method that visually represents the distance (or similarities) between a set of objects. Objects that are more similar (or separated by shorter distances) are placed closer together on the graph than objects that are less similar (or separated by longer distances). Here, MDS was used to analyze the similarities between the respondents and identify those whose responses were more extreme in relation to the whole group. The more extreme respondents were called outlier respondents. According to Malhotra (2012), Pinto (2012) and Hair et al. (2009), three parameters must be analyzed to determine whether the use of MDS is appropriate: stress, S-stress and R-squared (RSQ). According to Kruskal (1964) and Upton and Cook, (2002), the stress and S-stress must be lower than 20\% to validate an MDS spatial map, and according to Hair et al. (2009) RSQ must be greater than 0.6. The software chosen to perform MDS and calculate factorial scores (SPSS) was run with the following options: ALSCAL algorithm, Euclidean distance function (tests performed for normal and quadratic distance), ordinal scale, conditionality matrix and case analysis. After the MDS spatial map had been validated, the outlier respondents were identified and the corresponding data were excluded from the subsequent statistical analysis. 
The CSR practices (variables) were then ordered using the procedure in SPSS to generate factor scores. This procedure is characterized by a linear combination of a set of variables and assigns scores to each variable so that higher scores indicate a greater contribution to the process being analyzed.

The Factor Analysis procedure in SPSS was used only to order the variables and not to perform a scale reduction as in traditional exploratory factor analysis (EFA). The procedure searches for the best linear combination that explains the first factor in traditional EFA, as this covers the main variance of the data (Field, 2009). There is therefore no need to determine and analyze the minimum sample size, commonality, variance explained by the model or other statistical indicators. According to Hair et al. (2009), factor scores are dimensionless values calculated according to the variables that compose a factor and describe how much each variable is related to each factor or construct. Ordering of variables by means of factor scores provides more accurate results than the arithmetic mean because the mean evaluates the central tendency of one variable locally and is a descriptive statistic (Hair et al., 2005).

\section{RESULTS}

Forty-eight CSR experts answered the survey. The sample was classified according to respondents’ professional activities and academic qualifications. Forty percent are university professors or researchers, $31 \%$ work in industry and $29 \%$ are consultants. Forty-four percent have a PhD, 23\% a Master's degree, $21 \%$ a postgraduate non-degree specialization and $12 \%$ a Bachelor's degree. This information is summarized in Figs. 2 and 3.

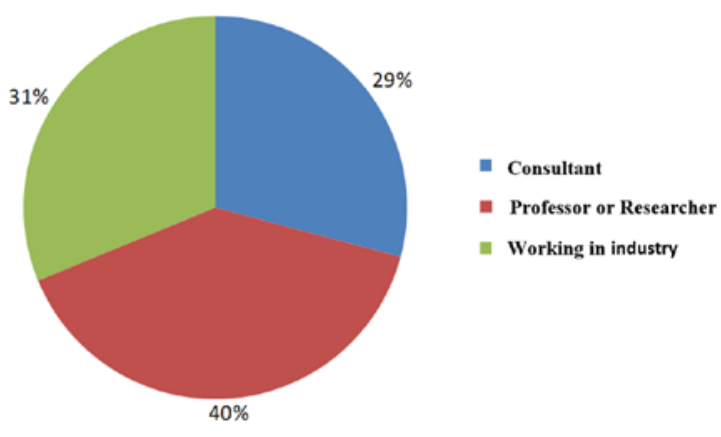

Fig. 2. Study sample classified according to respondents' professional activities (Source: The authors).

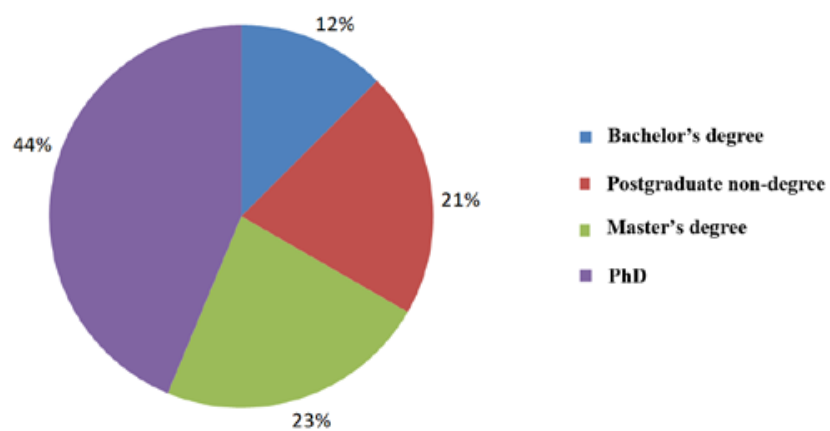

Fig. 3. Study sample classified according to respondents' academic qualifications (Source: The authors).

After the data-collection phase, MDS was used to generate a spatial map, as shown in Fig. 4. Respondents were referred to as $\mathrm{R} i$, where $i$ corresponds to the respondent's sequence number. 


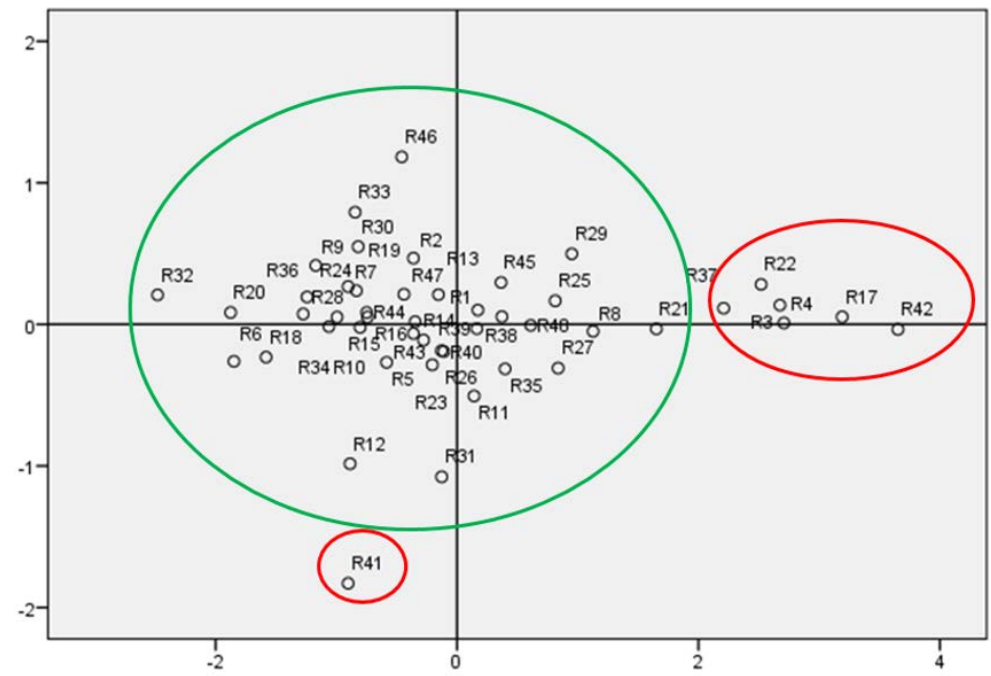

Fig. 4. Spatial map determined by MDS (Source: The author).

In Fig. 4 there is a large central group of respondents with similar behavior and outliers on the right of (R3, R4, R17, R22, R37 and R42) and below (R41) the central group. To confirm that these respondents were indeed outliers, the stress, S-stress and RSQ were calculated. The results for all three parameters, which are shown in Table 3, validated the spatial map.

Table 3. Values of the parameters for the spatial map in Fig. 4

(Source: Kruskal, 1964; Upton and Cook, 2002; Hair et al., 2009).

\begin{tabular}{|c|c|c|}
\hline Parameter & Result & Value for the MDS spatial map to be validated \\
\hline Stress & 0.10164 or $10.164 \%$ & $\begin{array}{c}\text { Less than } 20 \% \mid \text { Approx.10\% - “acceptable” (Kruskal, } \\
1964 ; \text { Upton and Cook, 2002) }\end{array}$ \\
\hline S-stress & 0.07 or $7.00 \%$ & Greater than 0.6 (Hair et al., 2009) \\
\hline RSQ & 0.96883 & \\
\hline
\end{tabular}

Validation of the spatial map in Fig. 4 confirmed that R3, R4, R17, R22, R37, R41 and R42 were outlier respondents. Forty-one respondents were therefore included in the factor analysis to order the CSR practices. The results of this analysis are shown in Table 4.

Table 4. Ordering of CSR practices by factor score (Source: the authors).

\begin{tabular}{|c|c|c|c|}
\hline Stage & CSR Practice & $\underline{\text { Factor }}$ & $\begin{array}{l}\frac{\text { Arithmetic }}{\text { Mean of }} \\
\underline{\text { Expert- }} \\
\underline{\text { assigned }} \\
\underline{\text { Scores }}\end{array}$ \\
\hline Act & Report CSR results to the stakeholders by means of annual reports, website updates, letters to shareholders etc. & 2.42762 & 4.95 \\
\hline Check & Evaluate CSR performance using pre-set indicators & 1.49307 & 4.56 \\
\hline Do & Develop technical structures for CSR such as integrated manuals, procedures, work instructions and processes & 1.0249 & 4.27 \\
\hline Do & $\begin{array}{l}\text { Develop a corporate culture that values CSR practices (long-term strategic CSR plans, codes of conduct, routines } \\
\text { for CSR etc.) }\end{array}$ & 0.97061 & 4.49 \\
\hline Plan & Develop global indicators and indicators to assess the performance of CSR & 0.85017 & 4.66 \\
\hline Plan & Identify the resources required for CSR & 0.81963 & 4.63 \\
\hline Act & Determine what to report in relation to CSR practices and the best way to do so & 0.68557 & 4.29 \\
\hline Act & Integrate new CSR knowledge into organizational processes. & 0.63984 & 4.17 \\
\hline
\end{tabular}




\begin{tabular}{|c|c|c|c|}
\hline Act & Consolidate procedures for continuous process improvement & 0.53994 & 4.37 \\
\hline Check & Monitor employees' behavior in relation to CSR practices & 0.52181 & 4.10 \\
\hline Act & Promote continuous improvement in the integration of CSR strategies and operations with management processes. & 0.3344 & 4.20 \\
\hline Check & Critically analyze the adequacy and functionality of CSR structures in light of the existing infrastructure & 0.32024 & 4.00 \\
\hline Plan & Secure top-management commitment & 0.30372 & 4.98 \\
\hline Act & $\begin{array}{l}\text { Present results aligned with the interests of stakeholders rather than just reporting stories and experiences related } \\
\text { to the organization }\end{array}$ & 0.11722 & 3.90 \\
\hline Do & Manage CSR knowledge and lessons learned to improve CSR performance & 0.11179 & 4.17 \\
\hline Do & Align social and technical structures for CSR & 0.05206 & 4.00 \\
\hline Do & Develop social structures such as teamwork, training and collective CSR competencies & 0.04675 & 4.20 \\
\hline Check & $\begin{array}{l}\text { Use different means for assessing CSR practices such as integrated audits, self-assessment and benchmarking to } \\
\text { ensure holistic assessment of CSR in both strategy and operations }\end{array}$ & -0.01448 & 3.90 \\
\hline Check & $\begin{array}{l}\text { Evaluate the adequacy of the integration between the CSR system and the management system implemented in the } \\
\text { organization }\end{array}$ & -0.07466 & 3.56 \\
\hline Do & Ensure transparency in the integration of CSR with the management systems implemented in the organization & -0.2037 & 3.71 \\
\hline Do & Integrate CSR by translating organizational objectives into tactical and operational ones & -0.36243 & 4.24 \\
\hline Plan & Explore individual and organizational competencies for CSR and clearly define responsibilities & -0.57202 & 4.17 \\
\hline Do & Integrate CSR across departments, functions and the whole supply chain & -0.66311 & 3.34 \\
\hline Plan & Perform an environmental scan to identify issues that impact the organization & -0.73923 & 4.61 \\
\hline Do & Respond appropriately upon transgression & -0.77819 & 3.83 \\
\hline Plan & Define CSR in the context of the organization and develop a business model for it & -1.00984 & 3.95 \\
\hline Plan & Define stakeholders and their requirements & -1.11476 & 4.22 \\
\hline Plan & Engage in stakeholder consultation & -1.57971 & 4.17 \\
\hline Plan & Ensure that different stakeholders' requirements do not pull organizational processes in different directions & -1.7171 & 3.71 \\
\hline Plan & Ensure that there are no clashes of interest/redundancies in different stakeholders' requirements & -2.4301 & 3.34 \\
\hline
\end{tabular}

The highest scores correspond to Report CSR results to the stakeholders by means of annual reports, website updates, letters to shareholders etc. and Evaluate CSR performance using pre-set indicators, while the lowest correspond to Ensure that there are no clashes of interest/redundancies in different stakeholders' requirements, Ensure that different stakeholders' requirements do not pull organizational processes in different directions, Engage in stakeholder consultation, Define stakeholders and their requirements and Define CSR in the context of the organization and develop a business model for it. All the CSR practices had mean expert-assigned scores of less than 5.0.

\section{DISCUSSION}

All the CSR practices evaluated by the respondents had means greater than 3.0 and less than 5.0, as shown in Table 4, indicating that CSR practices are applied superficially by companies in Brazil and that there are ample opportunities for improvement (it is important to remember that all practices were evaluated in terms of an evolutionary scale from 0 to 10). This agrees with the literature, according to which CSR projects in most companies in Latin America are still at the development stage and projects without a clearly defined scope or with conflicting aims are common (Lázaro and Gremaud, 2017; Pozas et al., 2015; Vives and Peinado, 2011). This result also corroborates Anholon et al. (2016) ideas and, in the opposite direction of the European Commission $(2011, \mathrm{n}$.$) and demonstrates that social and$ environmental concerns are not yet fully integrated into Brazilian company's operations. For Jørgensen 
et al. (2006), it is necessary to "root" values, rules and processes in the organization towards integration, but the findings show that this is not evident in the major of Brazilian companies.

It is possible to observe by the results obtained that there are difficulties in stakeholder's management and ensuring that their interests are contemplated in corporate strategies, corroborating the ideas of Vives and Peinado (2011).

In addition to the mean expert-assigned score, a factor score was calculated for each CSR practice to allow a comparative analysis of all the practices and highlight those that are implemented to a greater degree and integrated with management systems in companies in Brazil.

Based on the factor scores, two CSR practices deserve particular attention: Report CSR results to the stakeholders by means of annual reports, website updates, letters to shareholders etc. and Evaluate CSR performance using pre-set indicators.

Vivarta and Canela (2006) and Griesse (2007) argue that the first of these practices closely resembles the way in which the media dealt with issues related to CSR in Brazil in the 1990s. Of note in this regard is the campaign launched by the sociologist Herbert de Souza at that time to promote the idea of social reports. Although this practice had a significantly higher factor score than all the others, as the average score is less than 5.0 the respondents considered that it is being implemented superficially by companies in Brazil and that there are ample opportunities for improvement. This result is in line with findings by Borges et al. (2017), which identified improvements opportunities in sustainability reports published by Brazilian companies.

The second highest factor score corresponds to the evaluation of CSR performance using pre-set indicators. This is a significant result as this practice enables organizations to work on corrective action plans and, consequently, ensures that they improve continuously. Again, the respondents considered that this practice is being implemented superficially by companies in Brazil and that there are ample opportunities for improvement as the average score assigned by respondents is less than 5.0. This corroborates the assertions of Hubbard (2009), Roca and Searcy (2012) and Helleno et al. (2017), who argue that there are still improvement opportunities associated to the definition of CSR performance indicators in companies.

In contrast, according to the respondents, the five CSR practices with the lowest factor scores (Ensure that there are no clashes of interest/redundancies in different stakeholders' requirements; Ensure that different stakeholders' requirements do not pull the organizational processes in different directions; Engage in stakeholder consultation; Define stakeholders and their requirements; and Define CSR in the context of the organization and develop a business model for it) are the least integrated and least implemented of all the practices in the daily routines of companies in Brazil.

These five practices belong to the Plan stage of the PDCA cycle. As this stage refers mainly to the systematization of stakeholders' needs, it can be deduced that organizations in Brazil are not taking 
stakeholders' needs sufficiently into account. Furthermore, as the Plan stage is the first stage of the PDCA cycle and planning difficulties are transferred to the subsequent Do, Check and Act stages, practices in these three stages of the PDCA cycle may not be implemented as effectively as expected by companies in Brazil. It is important to remember the considerations made by Asif et al. (2013) and Caiado et al. (2017) about the planning phase. It is characterized as one of the most critical and important phase to integrate CSR practices into management systems and, if there is a poor definition of objectives and actions at the mentioned phase, the final result may be lower than expected.

Based on the observed results, it is possible to identify many improvements opportunities. Brazilian companies need to understand that the gains due to the integration between CSR practices and management systems, go far beyond simple social and environmental activities. Saeidi et al. (2015), Bernal-Conesa et al. (2016) and Esteban-Sanchez et al. (2017) have shown in their studies that CSR practices mitigate supply-chain risks, increase customer satisfaction and loyalty, make an organization more attractive to shareholders, and have a positive effect on the organization's profitability. Jhunjhunwala (2014) also found that the integration of CSR within an organization's business strategy increases the organization's chances of long-term success. Summarizing, CRS practices are directly linked to excellence in performance.

\section{CONCLUSIONS}

The objective of this paper was to evaluate the integration between CSR practices and management systems in companies in Brazil and to identify the best and least integrated practices. The integration model proposed by Asif et al. (2013) was used together with the perceptions of experts on CSR in Brazil. The research strategy involved sending a questionnaire to 184 experts, of whom 48 replied. The data collected were analyzed by MDS to identify outlier respondents, and factor scores were used to order the practices.

Based on the results, the objectives of the study were achieved. According to the respondents, all the CSR practices evaluated are implemented superficially by companies in Brazil, and there are ample opportunities for improvement. On a scale of from 0 to 10 , the mean expert-assigned scores for all the practices were greater than 3.0 and less than 5.0. Two practices obtained the highest factor scores: Report CSR results to the stakeholders by means of annual reports, website updates, letters to shareholders etc. and Evaluate CSR performance using pre-set indicators. Five practices associated with the Plan stage of the PDCA cycle had the lowest scores: Ensure that there are no clashes of interest/redundancies in different stakeholders' requirements; Ensure that different stakeholders' requirements do not pull the organizational processes in different directions; Engage in stakeholder consultation; Define 
stakeholders and their requirements; and Define CSR in the context of the organization and develop a business model for it.

In conclusion, there is still much to be done to ensure that CSR practices are properly integrated with the management systems in companies in Brazil and the values related to sustainable development are not properly "rooted" within the organisations. There is ample scope for improvement in all practices, and special attention should be given to the Plan stage of the PDCA cycle so that the needs of all involved stakeholders are considered and do not adversely affect the performance of subsequent stages of the PDCA cycle. Besides, Brazilian companies need to understand that the gains due to the integration of CSR practices and management systems, go far beyond simple social and environmental activities.

The main limitation of this work is the sample size as the results were based on the perceptions of 48 CSR experts. However, the experts have in-depth knowledge of the Brazilian context, and the results proved to be consistent for the statistical methods employed. While the authors believe that the results may be useful not only for individuals who work regularly with CSR in their companies but also for researchers, who can use them as the basis for further studies, the debate on this subject is by no means exhausted. There are many possible research area that may arise from the findings presented here.

Several future studies can be done on this topic. For example, a larger database can be combined with other statistical methods. Further researches could also be performed in a different country because of the multiplicity of factors that influence the implementation of CSR practices, such as the local cultural context, government support and management skills.

The authors intend to use this paper as the basis for a detailed study of the different stages in the PDCA cycle and the factors that are critical for the success of each stage in companies in Brazil. It is their intention to pay particular attention to the Plan stage of the PDCA cycle, as this had the lowest scores. It is hoped that such a study will enrich the literature on the implementation of CSR practices in Brazil and help create a knowledge base to assist future projects related to CSR.

\section{ACKNOWLEDGMENTS}

The authors thank the FAEPEX (of the State University of Campinas) for the financial support provided. A preliminary and reduced version of the results was presented at the VI 6th International Workshop Advances in Cleaner Production, hold in São Paulo - 2017. The article received special mention and we were invited to submit an expanded version for the special issue "Ten Years Working Together for a Sustainable World", dedicated to the 6th IWACP.

\section{REFERENCES}


Abreu, M.C.S., Barlow, C., 2013. A comparative picture of corporate social responsibility approaches by leading companies in the United Kingdom and Brazil. Soc. Responsib. J. 9, 571-588. doi:10.1108/SRJ-04-2012-0046

Abreu, M.C.S. de, Castro, F., Soares, F. de A., Silva Filho, J.C.L. da, 2012. A comparative understanding of corporate social responsibility of textile firms in Brazil and China. J. Clean. Prod. 20, 119-126. doi:10.1016/j.jclepro.2011.08.010

Anholon, R., Quelhas, O.L.G., Leal Filho, W., de Souza Pinto, J., Feher, A., 2016. Assessing corporate social responsibility concepts used by a Brazilian manufacturer of airplanes: A case study at Embraer. J. Clean. Prod. 135, 740-749. doi:10.1016/j.jclepro.2016.06.169

Aras, G., Crowther, D., 2009. The Durable Corporation: Strategies for Sustainable Development. Gower Publishing Ltd., Farnham, England.

Ashley, P.A., 2005. Ética e Responsabilidade Social nos Negócios. Saraiva, Rio de Janeiro.

Asif, M., Searcy, C., Zutshi, A., Ahmad, N., 2011. An integrated management systems approach to corporate sustainability. Eur. Bus. Rev. 23, 353-367. doi:10.1108/09555341111145744

Asif, M., Searcy, C., Zutshi, A., Fisscher, O., 2013. An integrated management systems approach to corporate social responsibility. J. Clean. Prod. 56, 7-17. doi:10.1016/j.jclepro.2011.10.034

Battaglia, M., Testa, F., Bianchi, L., Iraldo, F., Frey, M., 2014. Corporate social responsibility and competitiveness within SMEs of the fashion industry: Evidence from Italy and France. Sustain. 6, 872-893. doi:10.3390/su6020872

Bazillier, R., Vauday, J., 2014. CSR into (new) perspective. Foresight 16, 176-188. doi:10.1108/FS10-2012-0069

Beckmerhagen, I.A., Berg, H.P., Karapetrovic, S.V., Willborn, W.O., 2003. Integration of management systems: focus on safety in the nuclear industry. Int. J. Qual. Reliab. Manag. 20, 210-228. doi:10.1108/02656710310456626

Bernal-Conesa, J.A., Briones-Peñalver, A.J., De Nieves-Nieto, C., 2016. The integration of CSR management systems and their influence on the performance of technology companies. Eur. J. Manag. Bus. Econ. 25, 121-132. doi:10.1016/j.redeen.2016.07.002

Biasutti, M., Makrakis, V., Concina, E., Frate, S. (2018) Educating academic staff to reorient curricula in ESD. International Journal of Sustainability in Higher Education, 19 (1), pp.179-196, https://doi.org/10.1108/IJSHE-11-2016-0214

Borges, M.L. Anholon, R., Cooper Ordoñez, R.E., Quelhas, O.L.G. , Santa-Eulalia, L.A., Leal Filho, Corporate Social Responsibility (CSR) practices developed by Brazilian companies: an exploratory study, International Journal of Sustainable Development \& World Ecology. doi: 


\subsection{0/13504509.2017.1416700}

Boulouta, I., Pitelis, C.N., 2014. Who Needs CSR? The Impact of Corporate Social Responsibility on National Competitiveness. J. Bus. Ethics 119, 349-364. doi:10.1007/s10551-013-1633-2

Caiado, R.R.G, Quelhas, O.L.G, Nascimento, D.L.M., Anholon, R., Leal Filho, W. Measurement of sustainability performance in Brazilian organizations. International Journal of Sustetainable Development \& World ecology, 2017 doi: https://doi.org/10.1080/13504509.2017.1406875

Carroll, J. Douglas, and Arabie, P., 1980. Multidimensional scaling. Annu. Rev. Psychol. 31, 607-649. doi:https://doi.org/10.1146/annurev.ps.31.020180.003135

Carroll, A.B., 1991. The Pyramid of Corporate Social Responsibiiity: Toward the Moral Management of Organizational Stakeholders. Bus. Horiz. 34, 39-48. doi:10.1177/0312896211432941

Castka, P., Bamber, C.J., Bamber, D.J., Sharp, J.M., 2004. Integrating corporate social responsibility (CSR) into ISO management systems - in search of a feasible CSR management system framework. TQM Mag. 16, 216-224. doi:10.1108/09544780410532954

Claydon, J., 2011. A new direction for CSR: the shortcomings of previous CSR models and the rationale for a new model. Soc. Responsib. J. 7, 405-420. doi:10.1108/17471111111154545

Cramer, J., 2005. Company learning about corporate social responsibility. Bus. Strateg. Environ. 255266. doi:10.1002/bse.432

Dahlsrud, A., 2008. How Corporate Social Responsibility is Defined: an Analysis of 37 Definitions. Corp. Soc. Responsib. Environ. Manag. 1-13. doi:10.1002/csr

Delchet-Cochet, K., Vo, L.C., 2013. Classification of CSR standards in the light of ISO 26000. Soc. Bus. Rev. 8, 134-144. doi:10.1108/SBR-11-2012-0046

Douglas, T., 2007. Reporting on the Triple Bottom Line at Cascade Engineering. J. Glob. Bus. Organ. Excell. 35-43. doi:10.1002/joe

Elkington, J., 1998. Accounting for the Triple Bottom Line. Meas. Bus. Excell. 2, 18-22.

Esteban-Sanchez, P., de la Cuesta-Gonzalez, M., Paredes-Gazquez, J.D., 2017. Corporate social performance and its relation with corporate financial performance: International evidence in the banking industry. J. Clean. Prod. 162, 1102-1110. doi:10.1016/j.jclepro.2017.06.127

European Comission, n.d. Communication from the Commission to the European Parliament, the Council, the European Economic and Social Committee and the Committee of the Regions, in: A Renewed EU Strategy 2011-14 for Corporate Social Responsibility. p. 15.

Evans, J. R., Mathur, A., 2005. The value of online surveys. Internet Research, 15, pp.195-219. doi: $10.1108 / 10662240510590360$

Field, A., 2009. Discovering Statistics using SPSS, Third Edit. ed. SAGE Publication Ltd, London. Friedman, M., 1970. The Social Responsibility of Business is to Increase its Profits. N. Y. Times Mag. September 13. doi:10.1007/978-3-540-70818-6_14 
Galeazzo, A., Klassen, R.D., 2015. Organizational context and the implementation of environmental and social practices: What are the linkages to manufacturing strategy? J. Clean. Prod. 108, 158168. doi:10.1016/j.jclepro.2015.06.053

García-Rodríguez, F.J., García-Rodríguez, J.L., Castilla-Gutiérrez, C., Major, S.A., 2013. Corporate Social Responsibility of Oil Companies in Developing Countries: From Altruism to Business Strategy. Corp. Soc. Responsib. Environ. Manag. 20, 371-384. doi:10.1002/csr.1320

Gil, A.C., 2002. Como Elaborar Projetos de Pesquisa. Atlas, São Paulo.

Glac, K., 2015. Triple Bottom Line. Wiley Encycl. Manag. 2, 1-2. doi:10.1002/9781118785317.weom020216

Godoy, A.S., 1995. Introdução à Pesquisa Qualitativa e Suas Possibilidades. Rev. Adm. Empres. 35, $57-63$

Gray, D.E., 2009. Doing Research in the Real World, $2^{\circ}$ ed. ed SAGE Publications of London, Thousand Oaks, New Delhi and Singapore.

Griesse, M.A., 2007. The geographic, political, and economic context for corporate social responsibility in Brazil. J. Bus. Ethics 73, 21-37. doi:10.1007/s10551-006-9194-2

Hair, J.F., Anderson, R.E., Tatham, R.L., Black, W.C., 2009. Análise Multivariada de Dados, $6^{\circ}$ ed. ed. Porto Alegre.

Hair, J.F., Babin, B., Money, A.H., Samoel, P., 2005. Fundamentos de Métodos de Pesquisa em Administração. Bookman, Porto Alegre.

Halkos, G., Skouloudis, A., 2016. National CSR and institutional conditions: An exploratory study. J. Clean. Prod. 139, 1150-1156. doi:10.1016/j.jclepro.2016.07.047

Helleno, L., Moraes, A.J.I. de, Simon, A.T., 2017. Integrating sustainability indicators and Lean Manufacturing to assess manufacturing processes : Application case studies in Brazilian industry. J. Clean. Prod. 153, 405-416. doi:10.1016/j.jclepro.2016.12.072

Hubbard, G., 2009. Measuring organizational performance: Beyond the triple bottom line. Bus. Strateg. Environ. 18, 177-191. doi:Doi 10.1002/Bse.564

ISO, 2016. Benefits in applying ISO 26000: Selected case studies as a result of the SR MENA Project. Available at: https://www.iso.org/files/live/sites/isoorg/files/archive/pdf/en/srmena_factsheets.pdf Jhunjhunwala, S., 2014. Intertwining CSR with strategy - the way ahead. Corp. Gov. 14, 211-219. doi:10.1108/CG-03-2011-0021

Jørgensen, T.H., Remmen, A., Mellado, M.D., 2006. Integrated management systems - Three different levels of integration. J. Clean. Prod. 14, 713-722. doi:10.1016/j.jclepro.2005.04.005

Kruskal, J.B., 1964. Multidimensional scaling by optimizing goodness of fit to a nonmetric hypothesis. Psychometrika 29, 1-27. doi:10.1007/BF02289565

Lázaro, L.L.B., Gremaud, A.P., 2017. A responsabilidade social empresarial e sustentabilidade na 
América Latina: Brasil e México. Rev. Adm. da UFSM 9, 138-155. doi:10.5902/19834659

Malhotra, N., 2012. Pesquisa de Marketing: uma orientação aplicada. Bookman, Porto Alegre.

Mežinska, I., Lapiņa, I., Mazais, J., 2015. Integrated management systems towards sustainable and socially responsible organisation. Total Qual. Manag. Bus. Excell. 26, 469-481. doi:10.1080/14783363.2013.835899

Moldan, B., Janoušková, S., Hák, T., 2012. How to understand and measure environmental sustainability: Indicators and targets. Ecol. Indic. 17, 4-13. doi:10.1016/j.ecolind.2011.04.033

Mota, B., Gomes, M.I., Carvalho, A., Barbosa-Povoa, A.P., 2015. Towards supply chain sustainability: Economic, environmental and social design and planning. J. Clean. Prod. 105, 14-27. doi:10.1016/j.jclepro.2014.07.052

Passador, C.S., 2002. A responsabilidade social no Brasil : uma questão em andamento. VII Congr. Int. del CLAD sobre la Reforma del Estado y la Adm. Pública, Lisboa, Port. 1-13.

Pelliano, A.M., 2001. A iniciativa privada e o espírito público: a ação social das empresas do Sul do Brasil. IPEA, Brasilia, DF.

Pinto, J.S., 2012. Variáveis dos Atributos Complexidade e Incerteza em Projetos: proposta de criação de Escala de Mensuração 125/2012.

Pozas, M. del C., Lindsay, N.M., du Monceau, M.I., 2015. Corporate social responsibility and extractives industries in Latin America and the Caribbean: Perspectives from the ground. Extr. Ind. Soc. 2, 93-103. doi:10.1016/j.exis.2014.08.003

Quairel-Lanoizelée, F., 2011. Are competition and corporate social responsibility compatible? The myth of sustainable competitive advantage Franc. Soc. Bus. Rev. 6, 77-98. doi:10.1108/17465681111105850

Rahman, S., 2011. Evaluation of Definitions: Ten Dimensions of Corporate Social Responsibility. World Rev. Bus. Res. 1, 166-176.

Roca, L.C., Searcy, C., 2012. An analysis of indicators disclosed in corporate sustainability reports. J. Clean. Prod. 20, 103-118. doi:10.1016/j.jclepro.2011.08.002

Saeidi, S.P., Sofian, S., Saeidi, P., Saeidi, S.P., Saaeidi, S.A., 2015. How does corporate social responsibility contribute to firm financial performance? The mediating role of competitive advantage, reputation, and customer satisfaction. J. Bus. Res. 68, 341-350. doi:10.1016/j.jbusres.2014.06.024

Sarkar, S., Searcy, C., 2016. Zeitgeist or chameleon? A quantitative analysis of CSR definitions. J. Clean. Prod. 135, 1423-1435. doi:10.1016/j.jclepro.2016.06.157

Scholten, M., Caldeira, P.Z., 1997. O senso do escalonamento multidimensional. Análise Psicológica 1, 63-85.

Scott, W.R., Davis, G.F., 2015. Organizations and Organizing: Rational, Natural and Open Systems 
Perspectives.

Shnayder, L., Van Rijnsoever, F.J., Hekkert, M.P., 2016. Motivations for Corporate Social

Responsibility in the packaged food industry: An institutional and stakeholder management perspective. J. Clean. Prod. 122, 212-227. doi:10.1016/j.jclepro.2016.02.030

Shnayder, L., Van Rijnsoever, F.J., Hekkert, M.P., 2015. Putting your money where your mouth is:

Why sustainability reporting based on the triple bottom line can be misleading. PLoS One 10, 124. doi:10.1371/journal.pone.0119036

Silva, E.L., Menezes, E.M., 2005. Metodologia da Pesquisa e Elaboração da Dissertação, $4^{\circ}$ ed. ed. Florianópolis, SC.

Slaper, T., Hall, T., 2011. The Triple Bottom Line : What Is It and How Does It Work? Indiana Bus. Rev. 4-8.

Sobczak, A., Coelho Martins, L., 2010. The impact and interplay of national and global CSR discourses: insights from France and Brazil. Corp. Gov. Int. J. Bus. Soc. 10, 445-455. doi:10.1108/14720701011069678

UN Department of Economic and Social Affairs, 2007. CSR and Developing Countries: what scopes for government action? Sustain. Dev. Innov. Briefs 8.

Upton, G., Cook, I., 2002. A Dictionary of Statistics. Oxford University Press Inc., New York.

Visser, W., 2010. CSR 2.0 - The Evolution and Revolution of Corporate Social Responsibility, in: Pohl, M., Tolhurst, N. (Eds.), Responsible Business: How to Manage a CSR Strategy Successfully. Wiley.

Vivarta, V., Canela, G., 2006. Corporate social responsibility in Brazil: the role of the press as watchdog. J. Corp. Citizsh. 95-106.

Vives, A., Peinado, E., 2011. La Responsabilidad Social de la empresa en América Latina 468. doi:http://www.cumpetere.com/Documents/LIBRO\%20RSE.pdf

World Commission on Environment and Development, 1987. Our Common Future. Disponível em http//www.un-documents.net/. doi:10.1080/07488008808408783 